ACTA THERIOLOGICA

Vol, 27, 20: 275-282, 1982

\title{
Determining the Age of Bank Voles - a Laboratory Study
}

\author{
Torgny O. GUSTAFSSON, C. Bertil ANDERSSON \\ \& Lilian M. WESTLIN
}

\begin{abstract}
Gustafsson T. G., Andersson C. B. \& Westlin L. M., 1982: Determining the age of bank voles - a laboratory study. Acta theriol, 27, 20: 275-282 [With 2 Figs. \& Plate VII]

A method is described for determining the age of bank voles, Clethrionomys glareolus (Schreber, 1780), over 30 days of age. The method is based on the root length of the first lower molars. Four measurements of root length were made of 664 teeth from laboratory bank voles of known age. The best measurement was the length of the oral root from the upper part of the neck of the tooth, which allows age estimation of bank voles from the age of 30 days. The measurements of length of separate roots used by most earlier workers allowed age to be determined only in animals older than approximately 75 days and was thus considered less useful. The rate of growth of molar roots in this study was similar to that found in field studies.

[Dept. Zool., Univ. Lund, S-223 62 Lund, Sweden]
\end{abstract}

\section{INTRODUCTION}

Various methods are available for determining the age of bank voles, Clethrionomys glareolus (Schreber, 1780), from the development of molar roots (Koshkina, 1955 ; Zejda, 1960 ; 1961 ; 1977 ; Mazak, 1963 ; Tupikova, Sidorova \& Konovalova, 1968 ; Pucek \& Zejda, 1968; Lowe, 1971; Viro, 1974). Similar methods have also been described for C. rutilus (Koshkina, 1955 ; Tupikova et al., 1968), C. rufocanus (Koshkina, 1955 ; Viitala, 1971 ; Abe, 1976) and C. gapperi (Perrin, 1978).

In most cases the first lower molar, $\mathrm{M}_{1}$, is used ; in a few the second upper molar, $\mathbf{M}^{2}$. The length of separate roots is most often used for estimating the age of the animal, but sometimes the ratio of root length to length of the entire tooth is used (Koshkina, 1955; Tupikova et al, 1968). The age when separate roots are formed in the first lower molars is very variable, from eight to 18 weeks of age (Lowe, 1971). This great variability suggests that estimates of age based on molar root length are subjected to large variation. Also, the age of young animals can not be estimated with this method. For C. rufocanus, Viitala (1971) suggested that root length should be measured from the neck of the tooth, which is formed at $60-65$ days of age. In C. rufocanus this method 
made age estimation of very much younger animals possible and increased the precision of the estimate.

Only one of the earlier studies of bank voles (Mazak, 1963) used laboratory animals of known age, but only 40 teeth with developed roots were measured. All the others used wild voles and estimated age from knowledge of the breeding season. In none of these studies was it possible to estimate the precision of the method used.

This laboratory study presents a method for measuring the age of bank voles from the age of about 30 days and an attempt to estimate the precision of the method.

\section{MATERIAL AND METHODS}

The material consisted of first lower molars from 664 bank voles, 23 to 632 days old from a laboratory colony kept at the Department of Zoology, University of Lund, Sweden (Gustafsson, Andersson \& Westlin, 1980). The animals were kept in a light regime of $18 \mathrm{~L}: 6 \mathrm{D}$ at approximately $22^{\circ} \mathrm{C}$. Standard mouse food and water were always available and fresh carrots were supplied twice a week.

The teeth were classified in three categories: 1 . no neck formed, furrows run along the entire height of the tooth (Photo 1a), 2. neck formed, but roots still united (Photo 1b) and 3. two separate roots formed (Photo 1c). Root length was measured in categories 2 and 3 . In category 2 two measurements were made, C and $\mathrm{D}$ in Photo $1 \mathrm{~b}$, an in category 3 , four measurements, $\mathrm{A}-\mathrm{D}$ in Photo 1c. The length of separate roots, measurements A and B (Photo 1c), are the same as those used by most earlier workers, while the total root length, measurements $C$ and $D$, is comparable to that used by Viitala (1971) for C. rufocanus and by Tupikova et al. (1968) for C. glareolus and C. rutilus.

Teeth were measured to the nearest $0.05 \mathrm{~mm}$ using a low power stereo microscope with an ocular micrometer. A number of teeth with malformations of one or both roots (Photo 1d) were excluded.

\section{RESULTS}

In very young animals the furrows on the sides of the teeth reached the tooth base (category 1, Photo 1a). The neck of the tooth was formed by 25 to 30 days of age (Photo $1 \mathrm{~b}$ ). Teeth with a neck, but without two separate roots, were found between 25 and 190 days, whereas teeth with two separate roots were found from 51 days of age. The frequency of these categories is given in Fig. 1. It is clear from this figure that in most animals the neck was formed between days 26 and 32, while there was large variation in the time of formation of two separate roots. Some animals had formed separate roots already when 50 days old, while others still had unseparated roots when 150 days old. Fifty per cent of the animals had formed two separate roots by about day 75 
This suggests that determination of age from the length of the separate roots (measurements $\mathrm{A}$ and $\mathrm{B}$ in Photo $1 \mathrm{c}$ ) is rather crude owing to differences in the age when roots are formed in addition to the inevitable inter-individual variation in growth rate. Measurement of root length from the upper margin of the neck allows age estimates in younger animals and may increase the precision in older animals. To test this, results of age estimates based on the four different measurements given in Photo 1c were compared. Only 20 animals more than one year old

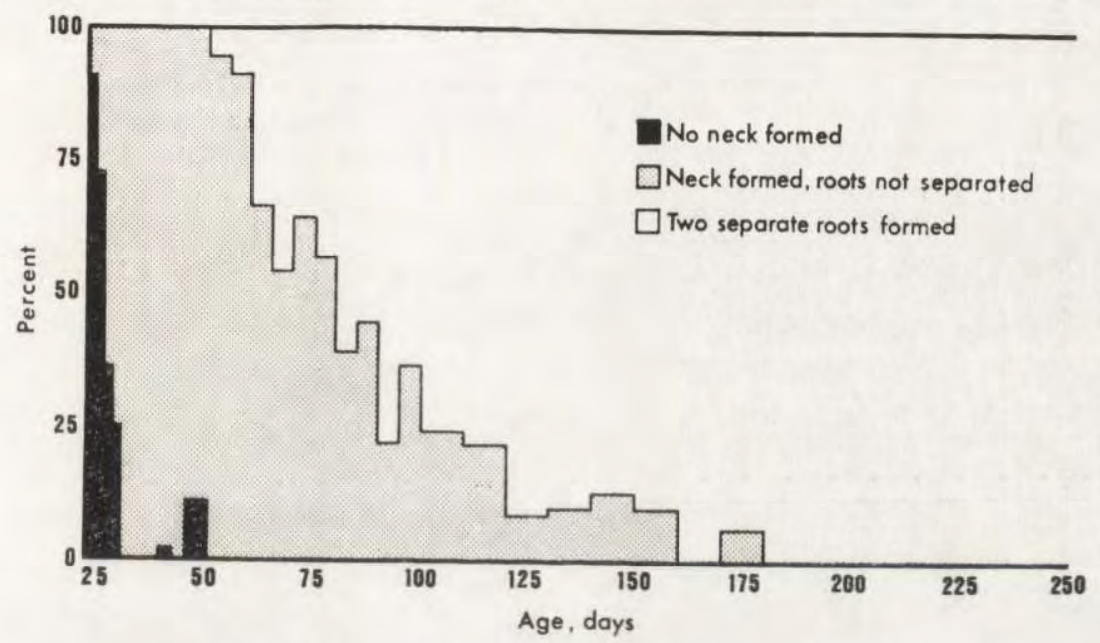

Fig. 1. Development of roots in the first lower molar in bank voles in relation to age. See also Plate 1.

were used and the lengths of the roots proved to vary widely from animal to animal (Fig. 2). Therefore, only animals younger than 365 days were used in the regression analysis. For teeth with separate roots the regression equations for measurements $\mathrm{A}$ to $\mathrm{D}$ were :
A. $y=0.159 x-0.389 \mathrm{~s}=0.163 \quad r=0.877 \mathrm{n}=294$
B. $y=0.176 x-0.388 \mathrm{~s}=0.183 \quad r=0.873 \mathrm{n}=294$
C. $y=0.186 x-0.027 \mathrm{~s}=0.202 \quad r=0.863 \mathrm{n}=294$
D. $y=0.196 x-0.051 \mathrm{~s}=0.197 \quad r=0.880 \mathrm{n}=294$

Where $y=$ root length in $\mathrm{mm}, x=$ age in months ( 30 day periods), $s=$ standard error of the estimate, $r=$ correlation coefficient and $n=$ number of animals.

The four measurements gave very similar results, with confidence intervals of similar width, approximately \pm 50 days for a 90 per cent confidence interval in all cases. No better results were obtained when means of measurements $\mathrm{A}+\mathrm{B}$ or $\mathrm{C}+\mathrm{D}$ were used. 


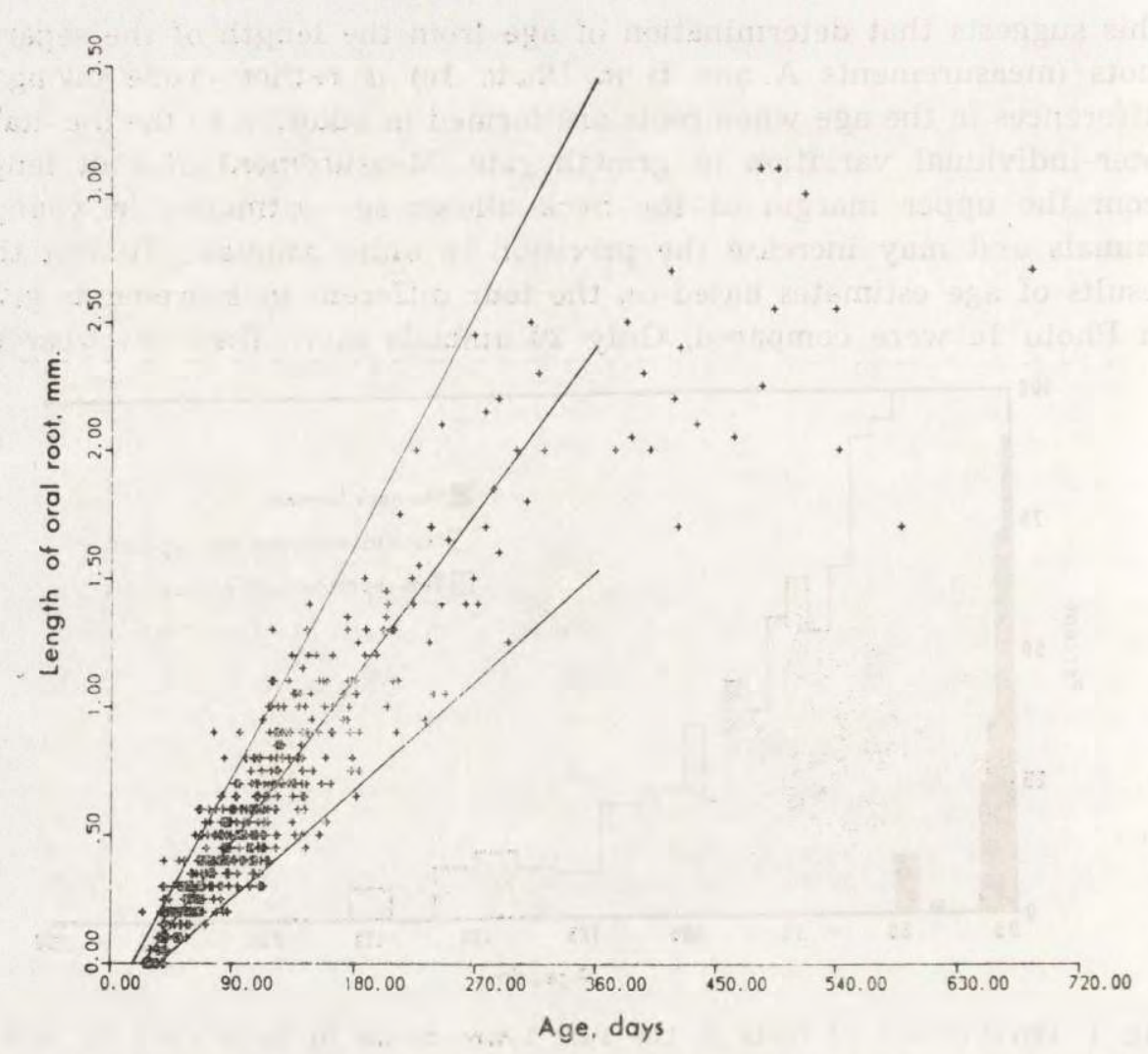

Fig. 2. Length of oral root of the first lower molar in bank voles, measured from the upper part of the neck (measurement D in Plate VII) in relation to age. Regression line and 90 per cent confidence limits for single observations of root-lengths calculated from the equation $\frac{y}{x}=\frac{\alpha}{x}+\beta$ (see text) are given.

If measurements C and D are used teeth can be measured as soon as the neck is formed. This means that the age of bank voles can be judged already from about 30 days of age, compared with about 75 days when using measurements A or B. The regression equations for measurements $\mathrm{C}$ and $\mathrm{D}$ for all teeth with the neck formed in animals younger than 365 days were as follows :

$$
\begin{aligned}
& \text { C. } y=0.206 x-0.103 \mathrm{~s}=0.170 \quad r=0.920 \mathrm{n}=597 \\
& \text { D. } y=0.209 x-0.144 \mathrm{~s}=0.158 \quad r=0.931 \mathrm{n}=597
\end{aligned}
$$

Symbols as explained above. Figure 2 gives the root-measurement D plotted against age, together with the regression line $y=0.209 x-0.144$. The residual plot showed that the variance of the root length increased 
with age, for which reason a conventional confidence interval could not be used. In the regression equation $y=\alpha+\beta x+\varepsilon$, where $y=$ root length, $\alpha=$ intercept, $\beta=$ slope, and $\varepsilon=$ error, the standard deviation of the error term $\varepsilon$ was assumed to be directly proportional to age, giving:

$V(\varepsilon)=\sigma^{2} x^{2}$

$V(\varepsilon)=$ variance of the error term

If this assumption is valid, the term $\varepsilon / x$ in the equation :

$$
\frac{y}{x}=\frac{\alpha}{x}+\beta+\frac{\varepsilon}{x}
$$

should have a constant variance :

$$
V\left(\frac{\varepsilon}{x}\right)=\sigma^{2}
$$

The residual plot for the equation (1) indicated that the variance was constant. A 90 per cent confidence interval for the root length was constructed using equation (1) (Fig. 2).

\section{DISCUSSION}

In earlier studies (see Introduction) where age estimates were based on the length of separate roots (our measurements A and B) the estimates could be made only in animals older than approximately 75 days. The main value of this study was to devise a method enabling estimation of age of bank voles from 30 days of age. The results are in good agreement with those presented by Viitala (1971) for C. rufocanus.

The measurement with the smallest standard error of the estimate and the largest correlation coefficient was measurement $D$, the length of the oral root from the upper part of the neck. This measurement also appeared to be better than the mean of $\mathrm{C}$ and $\mathrm{D}$. We suggest the use of this measurement for estimating the age of bank voles. Using measurement $\mathrm{D}$, the age of young bank voles can be estimated with considerable accuracy, for example $49 \pm 20$ days for root-length $0.2 \mathrm{~mm}$ and $96 \pm 40$ days for root-length $0.5 \mathrm{~mm}$ with 90 per cent confidence (Fig. 2). On the other hand, it does not seem possible to estimate the age of overwintered animals very accurately.

The growth rates of molar roots found here, $0.16 \mathrm{~mm}$ and $0.17 \mathrm{~mm}$ per month for aboral and oral roots, respectively, (measurements $\mathrm{A}$ and B), are in good agreement with results from field studies (Zejda, 1961; Viro, 1974). In spite of this, it is difficult to say whether these results 8 - Acta Theriologica 
are applicable on field samples. In nature the growth rates of molar roots were found to vary during the year (Lowe, 1971; Zejda, 1971; 1977; Wiger, 1979). This argues against a direct application of the present results for field samples. Another argument against using these results directly for estimating the age of wild bank voles is the occurrence of tooth malformations (Photo 1d). Such malformations are rare in field materials (unpublished observations), but Lowe (1971) described another kind of abnormal development of teeth in laboratory bred bank voles; no roots formed even in old animals. No explanations of these abnormalities have yet been offered.

In our opinion, the main values of this study are : 1 . the introduction of a method for estimating the age also of young bank voles, 2. an estimation of the precision possible with this method for animals of different age. Such an estimation is extremely difficult to obtain using field samples.

Acknowledgements: Financial support for this study was provided by the Swedish Natural Science Research Council and by the Royal Physiographic Society of Lund. We are indebted to Mrs. I. Mortensen for care of the animals.

\section{REFERENCES}

1. Abe H., 1976: Age determination of Clethrionomys rufocanus bedfordiae (Thomas), Jap. J. Ecol., 26: 221-227.

2. Gustafsson T., Andersson B. \& Westlin L., 1980: Reproduction in a laboratory colony of bank vole, Clethrionomys. glareolus. Can. J. Zool, 58: 1016-1021.

3. Koshkina T. V., 1955: A method for age determination in Clethrionomys and its use. Zool. Ž.,34: $631-639$.

4. Lowe V. P. W., 1971: Root development of molar teeth in the bank vole, Clethrionomys glareolus. J. Anim. Ecol., 40: 49-61.

5. Mazak V., 1963: Notes on the dentition in Clethrionomys glareolus in the course of its postnatal life. Säugetierkdl, Mitt., 11: 1-11.

6. Perrin M. R., 1978: Molar root-length as an indicator of age in Clethrionomys gapperi. Acta theriol., 23: 423-434.

7. Pucek J. \& Zejda J., 1968: Technique for determining age in the redbacked vole, Clethrionomys glareolus. Small Mammal Newsletter 2: 51-60.

8. Tupikova N. V., Sidorova G. A. \& Konavalova E. A., 1968: A method of age determination in Clethrionomys. Acta theriol., 13: 99-115.

9. Viitala J., 1971: Age determination in Clethrionomys rufocanus. Ann. Zool. Fennici, 8: 63-67.

10. Viro P., 1974: Age determination in the bank vole from the roots of the teeth. Aquilo, ser. Zool., 15: 32-36.

11. Wiger R., 1979: Demography of a cyclic population of the bank vole Clethrionomy glareolus. Oikos, 33: $373-385$.

12. Zejda J., 1960: The influence of age on the formation of the third upper molar in bank vole, Clethrionomys glareolus. Zool. Listy, 9: 159-166.

13. Zejda J., 1961: Age structure in populations of the bank vole, Clethrionomys glareolus. Zool. Listy, 10: 249-264. 
14. Zejda J., 1971: Differential growth of three cohorts of the bank vole, Clethrionomys glareolus Schreb. 1780. Zool. Listy, 20: 229-245.

15. Zejda J., 1977: A device to determine the birth date of Clethrionomys glareolus by the length of $\mathrm{M}_{1}$ roots. Folia Zool., Brno, 26: 207-211.

Accepted, December 24, 1981.

Torgny O. GUSTAFSSON, C. Bertil ANDERSSON i Lilian M. WESTLIN

OKRESLANIE WIEKU NORNICY RUDEJ - BADANIA LABORATORYJNE

\section{Streszczenie}

Opisano metodę określania wieku Clethrionomys glareolus (Schreber, 1780) u osobników ponad 30-dniowych. Jest ona oparta na 4 pomiarach długości korzeni pierwszego dolnego zęba trzonowego (Ryc. 1). Zmierzono długość korzeni 664 zębów nornic o znanym wieku, hodowanych w laboratorium. Najlepszym pomiarem okazała się długość przedniego korzenia mierzona od górnej części szyjki zębowej, która pozwala ocenić wiek nornicy od 30 dnia życia (Ryc. 2, 3). Pomiary długości poszczególnych korzeni, używane przez większość wcześniejszych badaczy pozwalają oceniać wiek tylko u zwierząt starszych niż 75 dni życia.

Tempo wzrostu korzeni zębów trzonowych u nornic w laboratorium było podobne jak u lowionych w terenie. 


\section{Plate VII}

First lower molar from bank voles of different age.

a. 26 days old. No neck formed.

b. 40 days old. Neck formed, roots not separated. Measurements C and D indicated.

c. 287 days old. Two separate roots formed. Measurements A, B, C, and D indicated.

d. 308 days old. Severe malformation of oral root. 
ACTA THERIOLOGICA, XXVII, 20 .

Plate VII

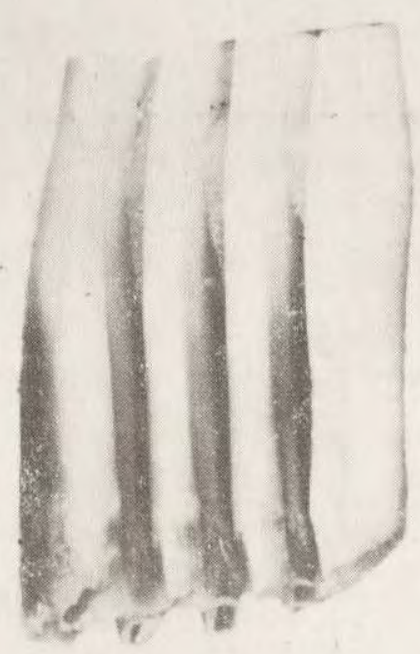

la

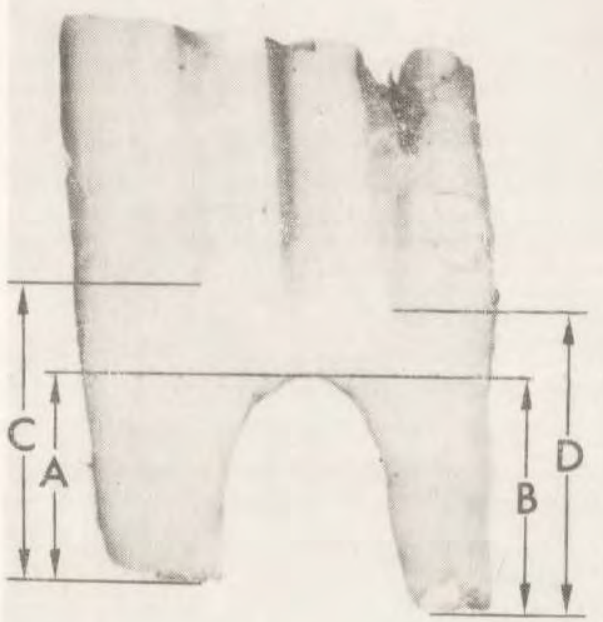

1c
Id

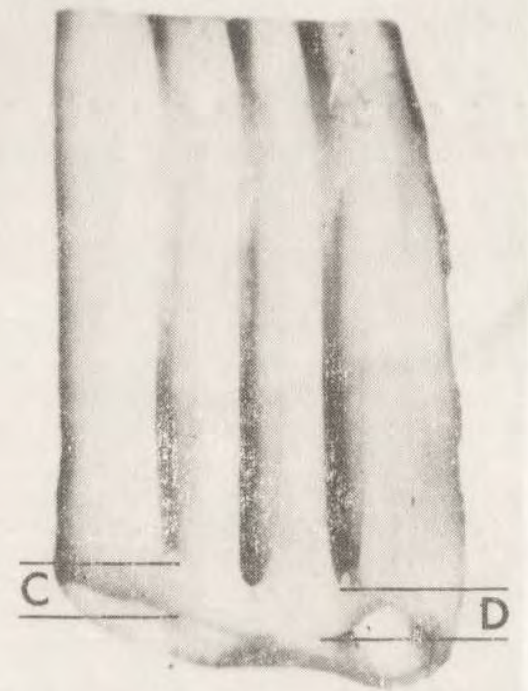

$1 \mathrm{~b}$

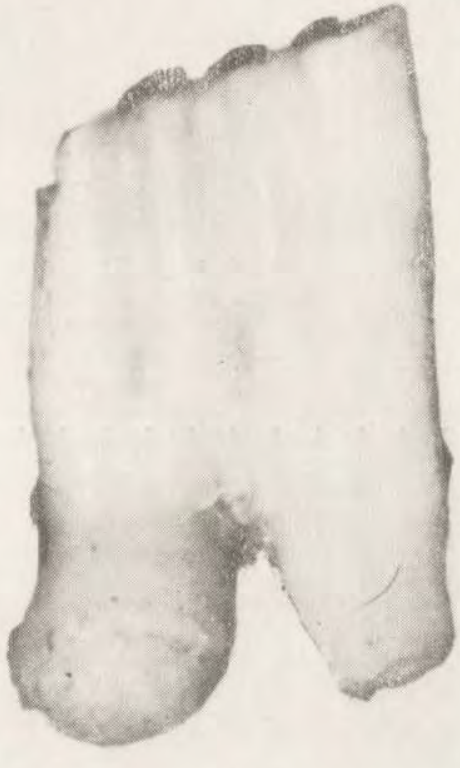

T. O. Gustafsson et al.,

auctores phot 